Please do not remove this page

RMIT

UNIVERSITY

\title{
Useful and priceless children in contemporary welfare states
}

Miller, Pavla

https://researchrepository.rmit.edu.au/esploro/outputs/9921858429101341/filesAndLinks?institution=61RMIT_INST\&index=null

Miller, P. (2005). Useful and priceless children in contemporary welfare states. Social Politics, 12, 3-41.

https://doi.org/10.1093/sp/jxi001

Published Version: https://doi.org/10.1093/sp/jxi001

Repository homepage: https://researchrepository.rmit.edu.au

(c) The Author 2005. Published by Oxford University Press. All rights reserved.

Downloaded On 2023/04/26 20:30:25 +1000 


\title{
PAVLA MILLER
}

\section{Useful and Priceless Children in Contemporary Welfare States}

\begin{abstract}
This article is an exercise in historical sociology. It deals with inconsistencies, absences, and unresolved issues in understandings of children's usefulness. Demography, histories of childhood, feminist research on housework and welfare states, time-use studies, psychology, ethnography, and "new sociology of childhood" often use incompatible notions of the productivity of children's time and effort. What does and does not constitute work is also one of the most keenly contested issues between children and adults. Taken together, these debates and skirmishes are at the heart of fundamental social categories. They help constitute the distinction between children and adults, work and learning, self-care and helping others, current and future usefulness, academic excellence and mediocrity, paid and unpaid effort and time, home, school, and workplace, altruistic and commercial exchange. The bulk of the article deals with countries of the North and draws on English-language studies. The concluding section uses material on countries of the South to suggest that the "majority world" might be pioneering new understandings and practices of growing up.
\end{abstract}

This article is an exercise in thinking through some inconsistencies, absences, and unresolved issues in social science understandings of the usefulness or otherwise of children and young people. ${ }^{1}$ Above all, it is an exercise in historical sociology. Without attempting a comprehensive coverage of each discipline, I refer to representative historical, quantitative, ethnographic, and psychological studies to 
highlight alternative, and frequently incompatible notions of childhood and youth. In writings on welfare states, for example, mothers, fathers, public instrumentalities, and private agencies are represented as potential partners in raising children. The young people themselves, in contrast, are almost universally depicted as a drain on resources, as precious rather than useful. Some commentators go even further. Children, many conclude, are not only useless, they have lost their erstwhile sentimental value to ambitious, financially pressed, or overworked couples (Friedman et al. 1999). Yet in the last chapter of a book that has since become a standard reference on the transition from useful to emotionally priceless children in early twentieth-century North America, Zelizer (1985) speculates that with increasing participation of married women in paid work, we might see a return of the useful child. The emergence of symmetrical gender relations, she notes, might well be complemented by new forms of equitable age relations, transforming priceless children back into "useful housechildren." In countries of the South, other theorists argue, children have never lost their usefulness; today, many are crucial contributors to new global industries.

Some of the questions arising out of these contrary depictions of young people have relatively straightforward empirical answers, available in existing time-use studies and examinations of welfare states and economic transfers. Other issues are more complex and require attention to conceptual and historical approaches to age relations and notions of work more generally.

The article begins with a brief historical overview of the overlapping legal precedents of age, gender, and class relations in common law jurisdictions. The next section looks at the way feminist writings on housework and welfare state regimes focus on women's but not children's labor. In this extensive literature, time-use studies tend to be employed to underscore women's productivity and children's uselessness. They also show that there are wide differences in young people's contributions, with some doing little and others a lot. The industrious minority is the focus of a range of recent ethnographies. I use several of these to show how housework can be thought of as a site of "negotiated childhoods."

The second part of the article alters the focus from current to future productivity of children's time and effort. From the perspective of developmental psychology, girls' and boys' work is essential to family survival in "preindustrial" communities but contributes little to the development of desirable psychological attributes in "developed" countries. Some contributors to the "new sociology of childhood" and to welfare state analyses similarly argue that the essence of children's productivity is their educational labor. The next section, on children 
and parents as actors, reflects on the way such incompatible interpretations can be theorized. In the various sites young people and adults go about their daily life, I argue, daily skirmishes help reconstitute the distinction between children and adults, work and learning, self-care and helping others, current and future usefulness, academic excellence and mediocrity, paid and unpaid effort and time, and altruistic and commercial exchange.

\section{Histories of Childhood, Marriage, and Mastery}

In the 1960s and 1970s, a number of scholars began to reinterpret histories of childhood and youth in Europe and its colonies (Ariés 1973; Bellingham 1988; Gillis 1981; Hawes and Hiner 1991; Johansson 1987; Mitterauer 1993; Tilly 1973). In a particularly influential contribution, Ariés argued that in past times, French children were not treated as different in kind from adults. Rather, they shared space and concerns with their elders and began taking part in everyday activities as their strength and understanding increased. Childhood was only discovered when, several centuries ago, the wealthy began endowing their sons and daughters with distinct sensibilities, dressing them in childish costumes, segregating them from adult life, and inventing new, agespecific institutions in which to confine them. Focusing on a later chronological age, other historians argued that adolescence as a special period in life, with its own distinctive psychology and needs, was invented by reformers and adopted by some privileged groups in the nineteenth century (Driscoll 2002; Graff 1991; Kett 1978; Musgrove 1964).

One theme in these histories overlaps with feminist work on patriarchal regimes, as well as with accounts of wage labor and class relations more generally. In jurisdictions drawing on English common law, the husband and father used to be the rightful owner of the labor of all those who resided in his household (Miller 1998, 2002). This power, enshrined since feudal times in a series of master-andservant statutes, drew parallels between husbands and wives, parents and children, and masters and servants: all owed masters labor and obedience in return for subsistence and protection. Although the relations of subordination overlapped, distinct branches of historical scholarship tend to deal with the way mastery was contested by workers, wives, young people, and those who spoke for children. A number of contributors to these diverse literatures argue that traces of patriarchalism remain embedded within contemporary class, gender, and age relations. Such continuity, some go on to say, is not simply the result of patriarchal resistance to change but has been reinvented through processes that included legislative innovation. 
Particularly useful and conceptually innovative contributions to these debates have been made by scholars working on marital property reforms in British and Anglo-American jurisdictions (Backhouse 1988; Cott 2000; Shanley 1989; Stanley 1998). During the nineteenth century, a series of legal reforms gradually extended to all women some of the protection equity law provided to the rich: they gave wives a qualified right to their own wages, protected their separate property against the claims of husbands and creditors, and enabled them to make wills. These acts fell far short of giving married women the same rights as single women or their husbands had, particularly because men retained the right both to the person of their wives and to their domestic labor. Nevertheless, they helped inspire a piecemeal process of innovation: small but increasing numbers of ordinary wives and husbands began to contract with each other for the performance of various forms of housework. When something went wrong and one of the parties sought legal remedy, the courts improvised to declare such contracts null and void. In conformity with laws of contract, they held marital agreements for the performance of domestic work to be without monetary value and therefore invalid. Because husbands already owned their wives' labor, having exchanged it for the promise of support, they could not subsequently buy it. Simultaneously, courts held that the agreements were unenforceable precisely because they constituted a contract, and marriage was by definition deemed to be defiled by the imposition of contractual arrangements (Siegel 1994, 2189).

Like other scholars, Siegel concludes that in construing the earning statutes to prohibit market relations in the family setting, and thus acting to differentiate the family and the market in law, courts acted to ensure that wives' work was to be performed subject to a different mode of exchange than their husbands': as a form of altruistic as opposed to interested exchange. In turn, such legally enforced altruism contributed to the fiction that housework has no economic value and more broadly helped establish the distinction between marriage and private enterprise, and the boundaries of the modern labor market (Siegel 1994, 2140). Today, courts recognize the validity of some prenuptial contracts but continue their opposition to anything resembling wages for housework (Silbaugh 1996). The "commercialization of intimate life," other scholars note, remains a keenly contested field of practice, research, and debate (Hochschild 2003; Layne 1999; Shrift 1997).

Histories of nineteenth-century age relations also deal with struggles about the ownership and control of dependents' time and effort, and the role of state agencies in adjudicating what is right and proper. Although disputes about children's wages scarcely touched 
the courts, common law notions of parents' property in children's labor were routinely used in actions for death or wrongful injury. As Zelizer (1985) and others argued, such trials became one of the sites where notions of priceless children were forged. Most provisions specifically relating to those below the age of majority, however, came under equity rather than common law and, as in the case of marriage, were initially restricted to those with property. In the name of parens patriae, equity courts protected heirs and heiresses and settled disputes regarding their estates. From the early nineteenth century, equity courts' jurisdiction was widened to all "infants" regardless of wealth. Factory acts, compulsory education laws, child protection statutes, gaming, street trading, and vagrancy laws all attempted to restrict what began to appear as young people's adult responsibilities, limit their range of occupations, and substitute the work of schooling for that of subsistence. Although most of the early measures directed at laboring children were ineffective, by the turn of the century they helped redraw the geography of everyday life. The most accurate general description of a twelve-year-old in 1800 was a young servant; at the century's close it was a pupil at school.

For children and parents of the laboring classes, such innovations recast older patterns of contestation about property and authority, both within households and between social groups. Working people desperately tried to keep their children away from the worst and most dangerous jobs. They favored protective legislation, but not if it meant their families went hungry. They campaigned for education and spent precious money on school fees, but fiercely defended their right to send children to work or keep them at home when needed; childishness and tumultuous adolescence were a luxury few could afford (Davin 1996; Miller 1986). Many parents demanded that their children be paid for attending school or at least for tasks like sewing and cleaning classrooms. School trustees and inspectors often sympathized with laboring people's needs, refused to fine them for breaking attendance regulations, and designed exemptions so sons and daughters of the poor could leave school when household necessity was particularly pressing. In many localities, children were provided with free breakfasts or lunches at school, so at least some of their subsistence costs were covered. In spite of such accommodations, contests about child labor and schooling opened new lines of conflict between laboring people and the state, as well as within the working class itself. In most countries, compulsory education was one of several measures that were welcomed by and benefited those better off but entailed disproportionate hardship for the poorest groups.

Tensions simmered not only between social groups claiming control over the time and effort of the young but also within individual 
households. Frequently, all family members agreed on the tasks to be done and struggled through adversity with the knowledge that their sacrifices were shared by their loved ones. Working-class autobiographies abound in stories of women's heroic efforts to keep the family together, children's pride in being able to make things easier for mother, and men's desperate search for work. But this was not the only tale to be told. Some fathers terrorized their families, others were useless as breadwinners, some mothers took to drink. Children too could precipitate a family disaster. Some refused to attend classes and left their parents facing calamitous fines for truancy. Others loved school so much they provoked violent conflicts about financial priorities at home.

Child labor was more than a matter of need, it also depended on understandings of obligations and responsibilities among household members; different ethnic groups frequently articulated schooling and the remunerative work of family members in different ways (Hogan 1985). Gordon (1989), writing about the United States at the turn of the nineteenth century, concluded that long before psychologists like Hall conceptualized adolescence as a period of stress, the immigrant poor were experiencing intense conflicts between parents and children. Many were keenly aware that the increased period of childhood dependency forced into paid employment women who were previously able to make ends meet with the earnings of sons and daughters. Such families overwhelmingly shared the social reformers' marked preference for the wife as a full-time homekeeper; they often considered it blasphemous that mothers should have to go to work if their able-bodied children were forced, by the very same reformers, to be "idle" at school. Frequently, adults considered child labor proper and young people's refusal to work inappropriate, whereas many of their Americanized children refused to get a job or kept their wages for themselves. Indeed, Gordon $(1989,188)$ argues that conflicts about children's work obligations accounted for the greatest number of reported child abuse cases before World War II.

With more or less sophistication, contributors to this historical literature tried to strike a balance between racism, class prejudice, and sincere attempts to prevent child exploitation; social control and the provision of useful knowledge; household necessity and parents' and siblings' nastiness; and collective emancipation and individual aspirations. Perhaps more important than any specific historical narrative has been the realization that the way past age relations are conceptualized makes a difference to the way young people are thought of today. Over the past three decades, one version or another of this argument informed revised histories of schooling, childhood, and youth; more rarely, it made its way into policies, government initiatives, and public campaigns. 
Many of the same laws that confirmed husbands' rights to the products of wives' labor, I have argued so far, also applied to children. The scholarly consensus is that although the flow of resources between spouses continues to favor men, that between the generations was reversed (Caldwell 1980). Over the past century, young people's dependence on adults expanded, as have their notions of rightful entitlement.

\section{Feminists, Housework, and Welfare State Regimes}

In feminist writings, studies that look at the gender division of domestic labor play a key role. It is here that the effectivity of public and private, ideological, and practical struggles for gender equity can be examined, empirically and over time. Whether inspired by inequitable distribution of work, power, and resources in the home or curiosity about young women's reluctance to have children, most of the studies conceptualize gender and age relations in markedly different ways. It is seen as morally right-if notoriously difficult to achievefor women and men to receive equal pay for comparable work and for spouses to share housework and childcare. Throughout, feminists stress that "the personal is political," and that social movements are appropriately engaged in struggles for equity, rights, and recognition. In most of this writing, children and young people appear as objects of care, consumers of emotion, goods and services, sources of mess, worry and expense-as well as of love and satisfaction when all goes well. Only rarely are they seen as fellow workers, as people whose individual and collective agency helps shape and redefine the social relations in which they take part. These depictions are undoubtedly influenced by historically constructed notions of the priceless child. But there is also another dynamic at play.

In the opening issue of Gender and Society, Thorne (1987, 86) noted that "both feminist and traditional knowledge remain deeply and unreflectively centered around the experience of adults." Children rarely appear on the public agenda unless they are defined, by adults, as a social problem - as a threat to adult society, or else as victims of adults. Socialization approaches similarly deal with children as learners of adult culture, rather than as actors in complex social relations. In starting with gender, feminist scholars often do not reflect upon their assumptions about age (Thorne 1987, 95). Comparing women's studies with the emerging field of childhood studies, Oakley (1994) similarly argued that feminist work on families, reflecting struggles to free women from compulsory motherhood and childcare, "resulted in an emphasis on women's experiences of children, rather than children's experiences of women (or of anything else). Children came to be represented as a problem for women." Writing 
in 1994, she concluded that although some feminist theorists revalued mothering and what they saw as women's unique caring propensities, the notion of children as women's problem persists in most feminist policy contributions. In part, Oakley notes, this is the result of the different composition of women's and "children's rights" movements. The women's movement, claiming rights previously regarded as belonging only to men-such as suffrage, participation in paid work, and bodily integrity - was by and for women. The children's rights movement, claiming a number of rights regarded as the exclusive property of adults, is complicated by the fact that it is largely not children but adults on their behalf who are claiming these rights. As was initially the case for women, much of the language of reform of children's rights tends to be phrased in terms of what other people consider to be in "their best interests," without systematically asking children what they themselves want or need. Women's studies arose out of women's insistence that they were the ones to study their own lives; children's studies today are not rooted in the same way in the movement of children to claim their own liberation. Similar points have been made by other scholars (Alanen 1994; Nieuwenhuys 1996). Solberg (1997, 142), for example, notes that "having women's experiences and activities as their point of departure, children are more often described as the receivers of women's work and attention ... while uncovering [the extent of] women's work, women's research has effectively covered up the work of children." Readers of Social Politics, to bring the matter home, are far more likely to consult mainstream economics and politics publications than the excellent journal Childhood.

Examined from the standpoint of gender relations, the general conclusion of international research is that women continue to do substantially more housework than men, particularly when children are born. Although there are some differences over time and between regions, a good proportion of these stem from variations in study design and reporting (Lee and Waite forthcoming; Press and Townsley 1998). Everywhere, women's increased participation in the paid workforce has had more effect on decreasing the time they themselves spend on housework rather than increasing the contribution of men. Almost uniformly, the greatest changes have been not in who does what but in men's professed belief that equitable contribution to housework is fair. As a number of researchers note, most heterosexual couples engage in what can be called pseudomutuality: "Men tend to inflate the size of their contributions and diminish the significance of their partner's contributions. Women often collude in these processes and usually found it difficult to raise these issues without, at the same time, raising the spectre of termination of the relationship" (Bittman 1999, 31; Gager 1998). Centuries of practical entitlement, buttressed 
by husbands' legal ownership of wives' labor, have proved resilient to domestic skirmishes and women's movements alike. These dynamics, many observers argue, affect fertility rates. Using data from a representative interview study conducted in Ontario, Canada, Matthews (1999), for example, concludes that "women and couples have fewer children than they desire because they have been unable to establish a satisfactory gendered division of labor on a microlevel, not because their belief in equality has resulted in a desire for few or no children." A number of demographers, too, argue that domestic inequity between adult heterosexual partners is one of the key factors behind falling birthrates (Heitlinger 1993; McDonald 2000).

Most commentators go on to say that women's double burden is affected-and can be alleviated-by the availability of market or state provided services, and the family-friendly or otherwise character of workplaces and other institutions. Looking back, they note that during the twentieth century, homes, workplaces, public institutions, and welfare states were built around the male breadwinner family, with men at work and women in the home. Now that women increasingly participate in the paid workforce, the articulation between social institutions needs to be redrawn. Scholars writing on welfare state regimes point out that in any such process, women and men of different social groups face different possibilities and constraints, woven from divergent histories of national states and social provision; changing economies and labor markets; international flows of finance, ideas, and people; and different cultural and material resources. In many instances, as happened in the European past with servants and mistresses, mutually dependent groups of people have begun to establish incompatible models of family relations. Middle class couples in Singapore and Hong Kong employ live-in maids, parents in Scandinavia make use of municipal housekeepers and parental leave, those in Australia outsource increasing amounts of food preparation, and mothers in the Phillippines and Mexico pay relatives to raise their children while they themselves work as nannies in distant lands (Anderson 2000; Hochschild and Ehrenreich 2002). Within this mix, a significant minority of women will choose-or will be constrained-to work only in the home. Society-wide, however, "the age of the housewife" has come to an end. It might well be that this development has in turn undermined the long-term sustainability of the domestically useless teenager.

\section{Time-Use Studies and Children's Uselessness}

Along the edges of studies dealing with distribution of paid and unpaid work between adults are findings on children's contributions (Larson and Verma 1999). In general, the results are similar to those 
regarding men. Although there are some significant exceptions, and any measurement is clouded by the frequent invisibility of children's work, on average young people in developed countries do little around the house and create more mess and bother than they clean. In a conceptually innovative paper based on a 1994 Eurostat interview study for Denmark, Bonke (1999), for example, estimates that in families with the youngest child under age seven, children contribute 6 percent toward the work they create; in families with the youngest child seven to fifteen years old, 29 percent; and in families with the youngest child over age fifteen, the supply of housework equals 38 percent of their total requirements. Like other researchers, Bonke found a wide gender disparity in the data he analyzed: girls at school age spend two hours and seventeen minutes on housework and boys twenty-eight minutes, girls over fifteen years old three hours and seveteen minutes compared to two hours and eighteen minutes for boys. Bonke also found that children in single-parent, particularly mother-headed families were much more likely to make themselves useful at home: 56 percent of children of single mothers participated in housework against 41 percent of children in couple families; the former worked on average five hours and thirty-eight minutes, the latter five hours and thirteen minutes.

A complementary form of thought-provoking analysis about a three-way division of domestic labor between mothers, fathers, and children is presented in Goldscheider and White's New Families, No Families (1991). In a chapter dealing with children's contribution to housework in the United States, the authors conclude that in white, two-parent families, teenage boys do hardly anything, but young women perform a substantial proportion of domestic work. Adult sons contribute no more to household work than preteen children and substantially less than their sisters. Neither do they contribute financially to their families: most evidence suggests that adult children living at home keep their earnings. These general trends differ somewhat in mother-headed, Hispanic, and black households, where sons and daughters contribute more, and white Southern households, where they contribute less, to domestic work. Children also do a greater share of domestic work in rural than in urban communities.

When the authors change focus from individual family members to whole households, the extent and significance of their findings emerges with more clarity. Women's increased education and participation in the paid workforce, particularly when combined with higher education of their partners, tends to make marriages somewhat more egalitarian. As far as women are concerned, however, little has changed with respect of the total housework they perform, because children proportionately decrease their share of the work: 
In families in which both parents are highly educated, the husbands' share of housework is 80 per cent greater than in families in which the parents have only completed grammar school. In contrast, children in highly educated families share only 68 per cent of the level of children in poorly educated families . . . children in more educated families observe greater sharing in household tasks between men and women. But they participate much less in these tasks than children in families where parents have less education. (Goldscheider and White 1991, 185)

In single-mother families [regardless of race] in contrast, the data reanalyzed by Goldscheider and White indicate that both boys and girls do twice as much housework than their counterparts in twoparent families. For instance, teenage boys in mother-only families actually share more in household tasks than do teenage girls in twoparent families (195). Such trends seem to have intensified over time. Comparing U.S. time-use data for 1981 and 1997, Hofferth and Sandberg (2001), for example, note that children in single-parent households have increased, whereas those in two-parent households have decreased the time they spend on household tasks.

When the combined evidence on gender and age relations is considered, Goldscheider and White (1991) conclude, routine explanations of the second demographic transition might need to be rewritten: "It may also be that the reduced fertility in modern families is a response to the parent-child relationship they have observed among their family and friends, in which their children's 'work' at school is seen as more important than their mothers' (and fathers') work in the home, and 'independence' often appears as noncooperation" (199).

In explaining very low fertility rates, demographers frequently note that decisions about whether or not to have a second child are far more influenced by mothers' circumstances than those regarding the firstborn. Children's propensity to assist parents in household and caring tasks, as far as I know, does not rate a mention in this literature. The evidence presented so far suggests that it should.

\section{Ethnographies of Useful Children}

Average statistics of children's household contributions are made up of young people who "do not participate in housework" (except for what is defined as self-care tasks), and others who do a great deal. This industrious minority has recently been the focus of a number of excellent ethnographies. Some young people, this literature argues, make important contributions to household and caring tasks, many work for pay or help run family businesses, others are key 
agents in immigrant families' settlement process, and a number assist in the running of their schools as unpaid helpers. Although general statistical overviews tend to imbue the reader with righteous indignation about young people's freeloading, ethnographies of helpful children inspire anger at the lack of appreciation of their labor. In a study based on English children's written depictions of what they do out of school, for example, Morrow (1996) takes issue with the majority of social science commentators who assume that all "children" are dependent, whatever their age. She is not interested in quantification, and her method does not in any case lend itself to estimating time use. What she does show, conclusively, is that some children have extensive responsibility for the running of the household or family business, as well as for looking after the young and the elderly. As she puts it, "There may be a continuum, from children who appear to make no contribution to the domestic economy, to children whose contribution is total and on whom the functioning of the household may depend, with the majority making contributions that fall somewhere between the two extremes" (Morrow 1996, 61).

More detailed studies of particular groups of children support Morrow's general argument. In an ethnography of an immigrant neighbourhood in central Los Angeles for instance, Orellana (2001) uses the example of one of her informants to document children's extensive role in their families' settlement process. Throughout, seven-year-old Eva is shown as a competent and willing assistant to her mother. She answers the door and, after first making sure of who the visitor is, offers her a drink, finds an age-appropriate toy for the visitor's baby, helps mother unpack groceries, gets her youngest brother out of the bath, dries and dresses him, reads stories to her siblings, washes dishes, vacuums, helps fold and put away the laundry, answers the phone, and takes messages for her father. In local understaffed and overcrowded schools, large numbers of other children volunteer as teachers' aides: "They distribute papers and lunch tickets, help other children with assignments, sweep the floors, clean the sinks, organise supplies, run errands, staple papers, file materials, read stories, and take young children to the bathroom, among many other things" (Orellana 2001, 379).

Valenzuela's (1999) work on Mexican immigrants in the same geographical area similarly notes that children performed a number of key roles in their families' day-to-day survival. They served as translators, interpreters, and teachers for their parents and younger siblings. On occasions, they intervened, mediated, or advocated on behalf of parents or their households during difficult financial and legal transactions and took an active part in resolving other complicated situations. Children were consulted about household decisions, such 
as paying bills or purchasing large consumer goods. Finally, they took on caring and household responsibilities. Nine- and ten-year-olds prepared food, dressed, bathed, transported, and cared for younger siblings and were often consulted by parents in dealing with the school (Valenzuela 1999, 731).

In addition to caring and household tasks, many children assisted parents with remunerative work, whether as cleaners, stall keepers, or homeworkers or else in family businesses. In one particularly thoughtful study of Chinese take-outs in England, Song (1996, 1999) for example argues that children as well as adults constitute a crucial "ethnic resource" for the viability and competitiveness of these businesses. The children provided an invaluable source of labor, usually working at the counter taking orders, but often also going back and forth between the front and the back to expedite things. Many helped with food preparation, cooking, and cleaning up after the shop closed. Mothers and daughters also performed most of the housework. Like Mexican immigrants in the United States, many Chinese parents, who typically had little or no formal education, relied on children for mediation with English-speaking professionals and for skills, such as bookkeeping, they themselves did not possess. One of Song's informants, as the oldest child, not only cooked, did counter work, and accompanied parents to most appointments and places but was responsible for the bookkeeping and business management of the shop by the time he was fifteen (Song 1996, 104).

Importantly for comparison with other young people, few of the children who grew up in their families' take-out shops understood their contribution to the shop as "work." Work was what one did, half-heartedly and within set hours, for impersonal employers in exchange for pay. Help, in contrast, involved an organic commitment to the family project; it meant giving your best and taking responsibility without being asked. This commitment expanded as one grew up, it became more complex as one's skills and abilities increased; it was rarely negotiated or discussed. Unlike most employment, helping the family was meaningful in itself. What Song called a "family work contract" was implicit in understandings upheld collectively by family members. Although many young people were keenly aware that they were missing out on a "real childhood" and "real parenting," most grew up with the knowledge that their family's livelihood depended on their own labor participation. As one young person put it, "It was the only way. Like my mum and dad can't speak English. What can they do? The best way is to open a restaurant or a take-away. I don't see any other way, to be honest, to survive. I accepted it completely" (Song 1996, 106). Similarly, according to another young person, "It was what you had to do to 
survive, if you're poor. It's not a matter of liking it or disliking it. . . We worked every night. You had to" (Song 1996, 110).

In their belief that whether they liked it or not, the work needed to be done, the Chinese children's responses were closer to those of housewives than typical teenagers. Some of the young people interviewed by Song derived pride and pleasure from their contribution to the family business, but others reported that they hated the work, and still others were ambivalent. Despite a range of diverse and often contradictory feelings, however, all felt that they had no choice in helping out; saying "no" after being asked to do something was simply not an option. Every young person remarked that "everyone else does it." Helping out, and a focus on collective rather than individual interests, was recognized by all the young people as a positive emblem of a common Chinese cultural identity in Britain. Besides, many children were keenly aware that their parents' pride was already compromised by economic hardship in an alien society, they did not want to make the situation worse by drawing attention to the parents' reliance on them. Throughout, Song insists that although helping out was "what everybody did," it was not an irrevocable part of Chinese culture but rather represented the best available transitional strategy of settlement in a new and frequently inhospitable country. Not only was the take-out business sector getting saturated, few children wanted to inherit their parents' shop, and most families' strategies revolved around helping their children have a different, better future.

Young carers face different challenges and constraints than children working in family businesses, but they, too, feel little choice regarding their domestic responsibilities. These industrious young people-children defined as carers of ill or disabled family membershave been discovered by welfare workers and the media in Britain and other countries in the 1990s. Since then, they became the focus of extensive policy and academic debates, and a number of more or less useful services supporting them and their families have been established (Olsen 2000; Roche and Tucker 2003). Importantly, many of the domestic tasks that partially define young caring are the same ones described as "good work," as distinct from exploitative child labor, a century ago. In this way,

The eldest child in a large family, contributing significantly to the care of infant siblings, is typically excluded from the definition of a young carer, whilst a sibling of a disabled child, performing largely the same tasks . . . is included. . . . Similarly, a child of a disabled single parent who finds herself doing most of the housework, cooking, cleaning and so on, is, typically, included 
in the definition of a young carer, whilst a child having significant homework duties in a so-called "normal family" is excluded. (Olsen 2000, 387, 391)

Olsen concludes that children's "right to a childhood" that their own families have failed, however unintentionally, to provide, continues to dominate both the discussions and the practical responses of various agencies and practitioners.

Children who work for wages have also become the focus of intensified public debates. In Britain, for example, between one-third and one-half of school-age children are in employment at any one time; before they leave school between two-thirds and three-quarters of teenagers will have held down a paid job. Some researchers and activists put most emphasis on documenting the extent of child employment, the links between poverty and child labor, and the hazardous, badly paid, and frequently illegal nature of the tasks young people perform (Lavalette 1996; McKechnie et al. 2000; Rikowski and Neary 1997). Others focus on the cultural significance of work in young people's lives. Drawing on the new sociology of childhood, they note that boys and girls need cash not simply to eat and take part in school excursions but to participate in nonschool cultural activities. Leisure pursuits, they argue, are significant to young people in proportion to their relative powerlessness in school and family lives. But children's leisure increasingly revolves around the buying of goods and services. For teenagers who do not have ready access to cash, getting a job is one of the few ways in which they can secure what they believe to be proper childhood (Mizen et al. 1999, 335, 433). Paradoxically, "real" childhoods have become so expensive that many children need a job to take part. Those too poor to afford bus fares, cinema tickets, or snacks are to all intents and purposes excluded from the social life of their peers (Ridge 2002).

\section{Negotiated Childhoods}

There is now something of a tradition arguing that reformers, psychologists, social workers, and educational personnel helped, through their practices, constitute "the modern child" (Henriques et al. 1984; Johnson 2001; Prout and James 1997). For a long time, such insights did not seem relevant to the mundane world of housework. It is precisely because she focused on this sphere that a paper on the distribution of household work in Norway by Solberg (1997) has been so influential. The author starts with the widely accepted premise that childhood is a social construction, but she takes it into new and theoretically innovative territory. Sensibly, she observes that 
the actual organization of daily life, allocation of tasks and responsibilities between family members, as well as laying down of rules and establishing routines is part of the empirical process of making particular types of childhoods. Certainly, the process starts with preconceptions of child nature and capacities, but these understandings change over time as different family members $d o$ their age and gender. In particular, young people allocated set responsibilities, and completing a lot of work without supervision, seem to grow perceptibly as they learn to assume control and increase their skills. On the other hand, children that complete as much work, but remain closely supervised helpers, seem to retain a childish smallness.

Solberg describes three different eleven-year-olds to make her point. Anne, who lives with parents and an older sister, understands herself as having extensive obligations and rights, not different in principle from those of her parents. Like the others, she does a quarter of the housework, decides how and when to do it, and prepares her own school lunches. Anne and her sister also receive a monthly allowance and buy clothes and whatever else they need. Bente and her brother, in contrast, have quite different obligations and rights from their parents. Mother makes sandwiches, and puts them in Bente's satchel in the morning. Bente is used to having clean clothes in the cupboard and the house being tidy without any effort on her part. She spends a lot of time with her mother and knows all the work this involves. She likes to help, but her mother is so efficient that this is seldom necessary. The third child, Carl, does as much work at home as Anne, but as mother's helper. It is mother who decides when, how, and by whom things are to be done. When he has nothing else to do, Carl likes to be asked to help. He gets a lot of praise and feels that he is a "good boy." But at other times he has entirely different plans, which are disrupted by his mother's requests. Solberg argues that through their differing everyday activities, Anne appears to grow bigger, whereas both Bente and Carl remain small in their mothers' eyes: the nature of childhood is transformed in dialectical relationship with the opportunities young people have for appearing able and independent.

Solberg combines this insight with an important methodological point regarding housework. In interviews with parents of a number of twelve-year-olds, she noted, the respondents made a point of saying how easy family life became compared to when the children were small: "Many things that earlier required an effort on the parent's part now take place 'by themselves." "For example, children can now

take care of their personal hygiene, dress themselves and prepare their own food when they are hungry. They can also organize the greater part of their everyday lives. ... They are able to tell the 
time and be punctual. The parents praised their children for being so independent and it was easy to gain the impression that much of an adult's work in connection with these children has "disappeared" compared to time when they were small. During the interview with the children, however, another way of expressing it seemed more obvious to me: the work has not disappeared; rather, a major part of it has been taken over by the children themselves. (Solberg 1997, 139)

Such metamorphosis of work into self-care has important crosscultural components. In reflecting on her practice as a psychologist, Goodnow (2002) for example recalled how in the 1980s she was asked by the Catholic Education Office to help them understand why Lebanese-Australian parents ignored advice about the need to prepare children for kindergarten by making sure they mastered skills such as buttoning their coats or tying their shoelaces. In the course of researching the issues, Goodnow was struck by the Lebanese-Australian mothers' frank rejection of any such tasks as appropriate for five- to six-year-olds (although the same children might well be expected to look after their younger siblings). The children were "too young." The tasks were "mothers' work." The help was "not needed." Not present, however, were the Anglo-Australian endorsements of such tasks, however small, as good for the development of "character" or for learning that "we're a family." Similar reflections, this time inspired by local disapproval of her daughter's untidy appearance, were made by a U.S. anthropologist in the course of her fieldwork in central Italy. Practicing as she was self-care and independence, the little American girl looked scruffy next to friends dressed meticulously by their mothers (Krause 2001, 156). A study comparing child-rearing in Nunga Aboriginal and white middle-class families in Australia highlighted further contrasts. The Aboriginal mothers purposefully brought up their children to be independent from as early age as possible, able to defend themselves and their siblings when threatened. They expected children to look after each other, to be emotionally and physically resilient, to be uncomplaining, able to laugh at themselves and not take themselves too seriously, and to know what they wanted and how to get it. To the Anglo mothers, the children initially appeared inadequately supervised, disobedient, and grubby. To the Aboriginal women, in contrast, the Anglo mothers appeared tense, overprotective, and ineffective in their reprimands, and their children selfish and incapable of looking after themselves and each other (Malin et al. 1997).

Solberg (1997) sets her discussion of useful children in the context of Norwegian women's increasing participation in full-time work. 
By the late 1980s, about four in five mothers with the youngest child aged between seven and eleven years were employed. At the same time, the proportion of full-time housewives among women between twenty-five to fifty-four years fell to 15 percent. Although mothers spent more and more time at work, children's school hours decreased: for ten- to twelve-year-olds, time spent in school was between four and six hours a day. Although some adult care was provided for younger children, there seemed to be general agreement, by both parents and children, that those ten years and older were capable of taking care of themselves and being at home without supervision. Young people were not simply playing or doing homework. Most seemed to assume care of the home, performing a significant share of housework, and attending to important tasks_-such as letting in tradesmen, taking phone messages, and picking up younger siblings-that simply required someone to be home. Children, Solberg concluded, have become the "new homestayers."

Reflecting on her earlier work on useful and priceless children, Zelizer (2002) concluded that "the creation of an ostensibly useless child never segregated young people from economic life in general. Under changed symbolic and practical conditions, the priceless child remained a consumer, producer and distributor. What's more . . . children engaged actively in bargaining, contesting and transforming their own relations with the economy" (391).

Drawing on the work of an authority on marketing and advertising to children, she noted that American youngsters between four and twelve have an annual income of over $\$ 27$ billion, spend $\$ 23$ billion, and save the rest. Through hints, requests, and outright demands, children also influence about $\$ 188$ billion of their parents' spending each year. For 60 percent of these young people, the no-stringsattached allowance constitutes the largest single source of income (McNeal 1999, 29, 69).

So has the era of the priceless child ended? The tentative answer for the United States, Zelizer believes, needs to take into account the growing inequality of national income, the extent of child poverty, as well as the largely undocumented child labor of immigrant and migrant workers. Given these factors, the priceless child is probably being wiped out among the poor and near poor. In the middle and upper classes, in contrast, the priceless child still reigns. Many parents, affected by time famines, bribe their offspring to assuage guilt about not being able to provide them with "natural," intensely parented childhood (Hochschild 1997, 216-17). Even when children do get a job, middle- and upper-class parents continue to justify it not on the grounds of economic utility but rather its contribution to moral upbringing (Zelizer 2002, 391). 


\section{Time-Use Studies and Children's Usefulness}

So far, this article has contrasted evidence of low average responsibility for housework among boys and girls in Western countries with arguments that the contribution of a minority is substantial and that of many scarcely visible. In all these studies, children's work, however minimal or extensive, is assumed to have a particular form of productivity. What children do can be called work because they produce useful things and services now and free adults for even more productive tasks. Children's productive activity, however, is often also thought of as preparation for future usefulness, rather than as something that has value at present. This, indeed, is a major justification for not designating it as work. This distinction between current usefulness and investment in future productivity comes out with particular clarity in time-use studies and some work on welfare state regimes.

Feminists employ time-use studies above all to investigate the changing dynamics of gender relations or else to estimate all types of value producing activity in a total economy (Ironmonger 1996; Waring 1988). Other scholars, too, use time as a measure of productivity, but within a considerably different intellectual project. In contrast to those who focus on what young people do now, they study children with a view to who they will become in the future. Here, value is not measured by the immediate usefulness of what is produced, nor by the commercial price it can fetch, but by future productivity. Drawing on psychosocial, human capital, and modernization theories, these writers argue that time spent in activities that build social capital benefits both individuals and society, whereas time spent in mindless and harmful pursuits is "wasted" from a developmental standpoint, impedes healthy socialization, and leads to social problems. As Hofferth and Sandberg $(2001,295)$ put it,

The development of a child from infancy to adulthood requires substantial parental and community investments of time, money, and psychosocial or emotional capital. . . Besides providing opportunities for engagement with others, activities provide contexts for learning. ... Each context engages participants in a set of behaviors and rules and results in learning skills and a body of knowledge. ... . In addition to cognitive skills, activities such as play and conversation provide opportunities for developing social and emotional skills. The quantity of time serves as an estimate of exposure to different social experiences, with more time leading to greater absorption of the skills and knowledge of that context.

Time well spent, the authors conclude, is associated with higher achievement, and is "linked to fewer behavior problems, as 
measured by the child's score on the Behavior Problems Index" (Hofferth and Sandberg 2001, 295).

The advantage of time-use studies is their comprehensiveness and broad focus. Their results trace a complex map of divergent patterns of daily life among girls and boys, in rich and poor countries, with different climates, economies, institutions, and customary practices. Although average figures are in many ways misleading, the studies do reveal vast differences in time use between countries of the North and the South, as well as considerable diversity between and within "postindustrial" societies themselves. Countries differ in average hours spent at school and in doing homework, in time allocated to housework and paid work, and time available for discretionary activities and for sleep. In all, the studies show that the rhythms of work continue to rule the rhythms of school for a large proportion of the world's population. In wealthy countries, school requirements and education markets are decisive-but do not dictate the patterns of everyday life uniformly. Although some young people do have ample time to make themselves useful out of school hours, others do not.

A recent comprehensive overview of around 260 English-language studies by Larson and Verma (1999) constitutes a valuable introduction to this literature. The studies show that in nonindustrial communities where children do not attend school, commitment of time to household labor starts young and becomes considerable with age, especially for girls. By middle childhood, many contribute more than five hours per day to subsistence activities. In some nonliterate populations, by early adolescence girls spend as much time on household labor as adult women. When children do attend school, the time they need to devote to household responsibilities is sometimes (but not always) reduced. In rural Nigerian families, for example, girls who attend school are expected to do the same chores as those who do not. In all societies, girls spend more time in household labor than boys. In nonindustrial settings, this is often balanced by boys' greater participation in income-generating work. By ages thirteen to fifteen, for example, boys in rural Bangladesh were found to spend an average of 2.7 hours per day in wage work, as compared to 1.1 hours spent by girls; for the lowest social class, the corresponding figures were 5.9 hours per day for boys and 3.5 hours for girls.

In what the authors call "postindustrial populations," it is school and not subsistence that looms largest in young people's lives. The school day itself varies from five to eight hours. In Bulgaria, Germany, Norway, Poland, and Romania, school takes up less than 5.5 hours per day, in the United States and Finland more than 6, and in France more than 7. In East Asia, the school day is eight hours long, and students attend an extra half day on Saturday. Schooling involves 
homework as well as school attendance. This was found to take up half an hour per day on average among twelve to seventeen-year-olds in the United States; just over an hour in Norway; 1.2 hours per day among French, Swiss, and Germans; 2.5 hours per day for samples of Polish, Romanian, Japanese, and Russian adolescents; and 3.0 hours per day among Korean high school students. In France, daily time allocated to school and homework combined averaged almost nine hours; in Norway and Germany, around six and a half. Studies that provide time estimates for an entire seven-day week show that schoolwork fills close to half of waking hours among Koreans compared to a quarter among U.S. adolescents (Alsaker and Flammer 1999; Larson and Verma 1999).

In the hours they have left after total schoolwork is accounted for, young people in "nonindustrial" and "postindustrial" countries spend, on average, substantially different amounts of time on domestic and remunerative work. In most nonindustrial, unschooled populations for which data are available, total labor exceeds six hours per day by middle childhood and eight hours per day by early adolescence. In literate, industrial societies, in contrast, housework and paid work combined average less than one hour per day across childhood and adolescence, except in the United States, where they add up to an average of one and a half hours per day. In these countries, not a single study showed average household labour to exceed one hour per day. In the United states, about forty minutes per day was the average for fifteen- to seventeen-year-olds. In France, young people spent on average less than ten minutes doing chores and six minutes shopping; in Poland, forty and twenty-two minutes, respectively. Among schooled populations in East Asia, children do even less: estimates of Chinese, Japanese, and Korean teenagers' daily contribution ranged from six to twenty-four minutes per day (Alsaker and Flammer 1999; Larson and Verma 1999).

According to Larson and Verma, one of the greatest differences between "postindustrial" countries is in the extent to which young people combine school and paid work. On average, U.S. high school students spent fifty minutes per day in employment, but a significant minority worked twenty or more hours per week. North European adolescents spent an average of fifteen minutes a day on paid work. Here again, there was considerable disparity within countries. The 1995 EU survey showed an average of 7 percent of thirteen- to seventeen-year-old people in full-time education also in paid work; in the United Kingdom, the proportion was 35 percent (Rikowski and Neary 1997). In Germany, 9.3 percent of students over age fourteen worked for pay the previous day, 17.5 percent in Norway and 8.4 percent in Poland, but none did in France and Russia (Alsaker and 
Flammer 1999). Among eleventh-graders, four in five had part-time jobs in Minneapolis, but only one in four of their Japanese and Taiwanese counterparts did. Those from poorer families were slightly less likely to be employed than middle-class young people, but were more likely to work longer hours.

Populations also differ greatly in the amount of waking time that remains after children's labor and schoolwork. For a rural, nonliterate population in Peru, 41 percent of six- to thirteen-year-olds' daytime hours were spent in discretionary activities, whereas for similarly aged children in a rural semiliterate population in Kenya, this figure was less than 10 percent. In nearly all nonindustrial populations, boys have more free time than girls. Among poor six- to twelve-yearolds in India, discretionary activities accounted for half of boys' but only a quarter of girls' waking time in rural areas, and two-thirds of urban boys' but only a third of urban girls' time. In literate postindustrial populations, gender differences in free time are minimal. What is striking, however, is the massive disparity in discretionary time between youth in different countries, with the United States at one extreme and East Asia at the other. Among U.S. children, discretionary time accounts for up to a half of waking hours, whereas among those in East Asia, between a third and a quarter. During school days, discretionary time accounted for a median of 4 hours across twelve European countries, from 2.7 hours in France to 5.6 hours in Norway (Alsaker and Flammer 1999; Larson and Verma 1999).

\section{What Constitutes Productivity in Children's Lives?}

Although children's work is acknowledged to be essential to family survival in preindustrial communities, it appears as unproductive when children's time allocation in developed countries is evaluated from the standpoint of psychosocial development. Housework in particular might result in meals, clean dishes, tidy rooms, ironed clothing-and less frantic mothers-but it does little for cognitive development and the accumulation of human capital. The authors surveyed by Larson and Verma (1999) agree that such activity has little educational value:

The great majority of research (primarily done in Western postindustrial nations) shows little effect of household labor on general qualities, such as responsibility and achievement, and little evidence of learning that carries over from household labor to other settings. For example, studies have failed to find a correlation between doing chores at home and being more responsible in school. (707) 
The fact that young people nevertheless spend some time doing housework "may be attributable to the greater value placed on teaching self-sufficiency in the individualistic cultures of the West." American parents, for instance, "report assigning chores principally because they believe they develop individual responsibility" (Larson and Verma 1999, 708).

Critical scrutiny of such theorizations should alert us to equally significant blind spots in feminist and demographic studies of housework. Psychologists tend to see schoolwork as productive and housework as a waste of time, whereas many feminists regard housework but not schoolwork as productive. When the time allocation for domestic and remunerative work of young people in developed and developing countries is put side by side, children in wealthy countries do indeed appear (on average) to be precious and useless. In terms of their contribution to the household economy, most constitute liabilities rather than assets. The fact remains that even though it does not seem to produce anything of value as far as present political economy is concerned, many children put in remarkably long hours each day into what, from their perspective, unambiguously counts as work. As one Australian grade-three pupil put it, "You have to wake up early in the morning and you have to get dressed and come to school and then, after all that hard work, they give you more hard work" (quoted in Goodnow and Burns 1985, 44). As anyone who has taken part in conversation to the effect: "Could you clean the kitchen?" "Can't you see I am trying to do my homework?" knows only too well, what counts as work is not just an abstract philosophical problem; it has (keenly contested) practical effects.

Some of these issues are the subject of a provocative paper by one of the leading contributors to the new sociology of childhood. In "From Useful to Useful," Qvortrup (1995) revisits some of the historical themes canvassed in the first part of this article. Most scholars accept the general proposition that children's usefulness decreased with the enforcement of compulsory schooling, but Qvortrup argues that both Zelizer and Caldwell were wrong to assert that the flow of resources between the young and old was reversed in the late nineteenth century. He also disagrees with those who recognize children's continuing usefulness in terms of what he calls "more or less ephemeral activities outside school—such as gainful employment and household chores" $(1995,51)$. Although it is true that the flow of resources between children and parents has changed, he notes, that between the generations had not. Although children have become useless from the standpoint of their own mothers and fathers, they are of essential usefulness to the society at large: "Children by means of their school labor are a part of the societal division of labor; their input therefore 
assumes the nature of an investment in society and thus should be measured not on the family budget, but on the national budget" (Qvortup 1995, 59). As he summarizes the argument, "We have seen no reversal of direction of the generational flows compared to the preindustrial period. There has, though, been a change in the locus of the generational flow from the young: it used to be within the family, while it now flows to the whole society to be distributed according to rules completely different from those applied in the family" (70).

Qvortrup refers to changing need for skills to put his argument on a historical basis. In preindustrial times, he argues, children's manual labor prepared them for their future role in society, whereas school attendance prefigured the future. Mass schooling became dominant at the beginning of the twentieth century when it was demanded by a particular form of modern industrial economy. Now, children's manual labor is more and more residual, and educational work has become essential. This transformation, demanded by the changing nature of the economy, cannot be taken as evidence of a decrease in children's usefulness. Rather, given the economic need for an educated workforce, children's (educational) labor has a value (Qvortrup 1995, 53).

Qvortrup acknowledges that there is no simple link between effort at school and adult employment and remuneration. Some people, moreover, work only in the home, many remain unemployed, and others develop an incapacity. Whatever pensions or benefits they receive have nothing to do with what they did at school. Rather, the question is why children must necessarily defer their reward in what Corrigan (1990) called an "implied contract of deferred gratification" or "a logic in which their acceptance of subordination or giving obedience now, will yield up superordination and encasheable knowledge later." Children, Qvortrup emphasizes, are "the only group in society that is forced to do obligatory labor without currently being paid for it” (Qvortrup 1995, 68-69).

As radical educationists point out, schools not only help shape the skills and attributes of the next generation of workers, they also contribute to reproducing the social relations of production. In systematically unequal societies, the greatest disaster schools could cause would be to teach so well that all children succeeded. Who would then accept deskilled and degrading jobs? Who would be resigned to working in positions that kill initiative and dull the intellect? How would people put up with dividing employment so many work such long hours their health is endangered, while others lose skills and self-confidence during long months of unemployment? Certainly, schools produce social capital. But their work of manufacturing failure is just as important.

Such reservations aside, Qvortrup's dismissal of children's domestic and paid work contributions as relatively trivial, and his emphasis on 
relations between generations rather than age relations within families, has strong parallels with influential analyses of welfare states. One of the best-known feminist theorizations of these issues is Folbre's Who Pays for the Kids? As she put it: "Children, like the environment, are a public good. The individual decisions that parents make about childrearing, and the level of resources that they can devote to this work, have economic consequences for everyone" (Folbre 1995, 254).

Building on these and other arguments, policy analysts in a number of welfare states have repeatedly condemned the lack of social resources devoted to the young and their families, and called for a new "social contract between the generations." There is some evidence that such redirection might be under way. Policy emphases on "active population," an emergent "social investment state" in countries such as Canada and the United Kingdom, and focus on investment in children as worker/ citizens of the future, have begun to have some (uneven) effect on funding priorities (Jenson and Saint-Martin 2003). Commenting on the United Kingdom, Lister for example concludes that "we are . . . witnessing a genuine, unprecedented, attempt to shift the social priorities of the state and nation to investing in children" (Lister 2002,17).

However one theorizes such issues, it is clear that their gross outcomes vary markedly between countries. Just as national education systems demand diverse time commitments from their pupils, so welfare states differ in the extent of public support provided to children and their carers. Just as there are more or less family-friendly states and institutions, so there are polities where young people can achieve independence-and realize some of the investment they made in their own "human capital" - with more or less ease.

An indication of this diversity is contained in a report on the Luxembourg Income Study dealing with Organisation for Economic Co-operation and Development members, several East European countries, and Taiwan. According to the authors, the likelihood that a randomly picked child will live in a poor family ranges from 1.8 percent in the Czech Republic to 21.2 percent in Italy, 21.3 percent in the United Kingdom, and 26.6 percent in Russia. The rate for Scandinavian countries is 3.4-4.5 percent, and that for Canada 16 percent and Australia 17.1 percent. More than 26 percent of children live in poverty in the United States despite the fact that after Luxembourg, it has the highest national income of the countries studied (Bradbury and Jäntti 2000, 14-15).

In many countries, children of single mothers are the most likely to be poor. But just as gross domestic product per capita is not a good predictor of child poverty, so single motherhood is not necessarily linked to social disadvantage. Across the countries for which data were analyzed, the proportion of children living in lone-mother 
households varies considerably. It is negligible in Ireland, Spain, Italy, and Taiwan but substantial in the United Kingdom (19 percent), the United States (15 percent), Sweden (15 percent), Norway (14 percent), and Denmark (13 percent). In all countries except Poland, children in single-mother households are more likely to live in poverty than those in two-parent households, but sometimes, as in Sweden, Hungary, and Russia, only marginally so. In four wealthy countries, however, the differences are startling. In the United States, 16.7 percent of children in two-parent households but 59.6 percent of those of single mothers live in poverty. In the United Kingdom, the corresponding figures are 17.5 and 40.3 percent, in Canada 12.3 and 45.3 percent, in Germany 8.5 and 43.3 percent, and in Australia 14.7 and 38.3 percent (Bradbury and Jäntti 2000, 23; Christopher 2002).

Young adulthood, too, is lived within markedly different constraints in different regions. A recent comparative paper by Smeeding and Phillips (2002), for example, notes that different types of welfare states differ greatly in the mix of there ingredients: employment sufficiency, welfare state support, including that for human capital building investments such as education, and familial support in cash and in-kind. These have different effects on young people when examined separately and together. Combined with different patterns of cultural preferences, they produce extraordinary differences between countries with respect to three key transitions from youth to adulthood: the move out of parental home, the change from single status to living with a partner, and the transition from childlessness to parenthood (Cook and Furstenberg 2002; Iacovou 2002).

In their theorizations of social contracts between generations and the flows of resources between the young and the old, Qvortrup and Folbre (and in a different way developmental psychologists) depict one side of Janus-faced social relations. As they convincingly demonstrate, young people labor to accumulate individual qualifications and, as a group, social capital. In their writings on everyday household transactions between parents and children, Zelizer, Morow, Solberg, and their colleagues compellingly depict the other Janus face: industrious and priceless children performing and consuming household, caring, and remunerative work. Qvortrup is correct to say that Zelizer's early work neglects the societal productivity of children's educational labor but wrong to dismiss the workings of the household. From the perspective of teachers and society as a whole, schools are indeed where (current) examination results and (future) social capital are produced, and teachers' labor and educational funding spent. From the perspective of parents and students, in contrast, schools are where students' energies and household members' care, worry, and expense are consumed, whereas households are 
where children are born and nurtured and their capacity for schoolwork reproduced.

\section{Children and Parents as Actors}

Today as in the past, the various participants in these multifaceted social relations are engaged in ongoing struggles and debates about what does and does not count as work, what constitutes unavoidable duty, a negotiable claim on one's time, an entitlement or imposition, compensatable expenditure of effort, commercial exchange, or loving care. The shifting outcomes of these skirmishes matter considerably to individuals, families, schools, states, and economies alike.

While groups of industrious children grow into or find they need to assume major responsibilities for the running of their households, a more common experience is a drawn out and often unsatisfactory effort to negotiate competing needs and understandings. Some parents claim that young people have a straightforward obligation to contribute to their own upkeep, at least to the extent of cleaning up after themselves. Many more justify requests for housework in terms of preparation for the future, the acquisition of valuable skills and responsibilities that will be necessary in later life, rather than in terms of equitable division of work that needs to be done now. The problem, as Lee et al. (forthcoming) note in reviewing a number of U.S. studies, is that

many children ... do not consider their involvement in household chores as an opportunity to learn valuable skills. . . . Adolescents have a different view about their participation in household duties from their parents. . . . [They] feel little responsibility for home chores and experience parental request of tasks as harassment. ... Housework is consistently reported as one of the most frequent sources of conflict between parents and adolescents.

As one typical interview study conducted in Australia found, the various strategies parents use to get things done rarely work; some are acknowledged to be both ineffectual and morally suspect (Gill 1998). One father, a full-time gardener, summarized a common predicament: "We threaten them a lot or take things off them like privileges but it is always handed back." Although parents in the study did not believe that children should be actually paid for each task, they did not rule out the possibility of rewards. As among the 1920s U.S. families described by Zelizer, some parents attempted to foster a work ethic by giving children pocket money for making their own bed, ironing, washing the family car, and lawn mowing. On their 
part, children used intensified contributions to housework as currency to gain parental approval, money, or other privileges. Parents who paid children for housework reported difficulties as children mastered the principles of market exchange and began renegotiating terms and conditions with their "employers." In one instance, a mother reported that "our son who is 11, has stopped making his bed because he thought he didn't get enough money to do that" (Gill 1998, 306). Similarly, in the accounts of English children's nonschool activities analyzed by Morrow (1996, 68,

Some boys saw their housework as a way of earning money, for example, one 12-year old boy who wrote "I . . . help around the house. . . . Nearly every weekend and holiday I get a list of jobs that I have to complete and I always ask for money for doing them". One or two older boys saw housework in purely instrumental terms, as the only way of generating income, like this 15 -year old boy who wrote "Basically what I do when I am not at school is housework. I haven't got a job so if I want money I have to work around the house for it."

Such research suggests that young people share notions of property in their own labor, which are at variance both with the expectations of their parents and legal definitions of the home as a sphere of altruistic exchange. Although most welfare states are tardy in recognizing parents' child rearing, and the children's own educational labor, through budget allocations, many young people obtain what are in effect wages for housework, and in this way contribute to the "commercialisation of intimate life" (Hochschild 2003). Although children tend to be jealous of their own expenditure of time and energy, most have a firm sense of entitlement to the time, resources and unpaid labour of their parents. As every parent knows, children are supported in their negotiations by a powerful sense of shared expectations. ${ }^{2}$ This powerful collective agency does not have any of the characteristics of a recognized social movement, yet underpins what, on a societal scale, is a massive flow of (private) resources between the generations.

As teachers know equally well, many young people are also lamentably backward in acknowledging the propriety of hard (unpaid) work at school in exchange for future prosperity. In Australian work drawing on "cultural capital" theories, Teese and Polesel (2003) point to some systemic sources and implications of this reluctance. Like other writers within this tradition, they note that young people prefer subjects where they work in groups, and where results are tangible and valuable in themselves. This is where their effort has concrete results, which serve to give them confidence in their own ability to transform the world. But doing well in these subjects, however beneficial educationally, 
does not confer a competitive advantage in examinations that count for university entrance. The most academically profitable subjects, in contrast, revolve around a high degree of abstraction. Depicting abstract worlds that can be occupied only through formal learning and protracted withdrawal from economic life, they are concerned with logical operations, grammars of mathematical or linguistic rulesand in many ways approximate the cultural orientations of wealthy, professional families. The minority who do well in such subjects tend to enjoy them; to many, mathematics classroom resembles a "laboratory where you learn to use tools," or even "a sportsground where you are training to win." Those who struggle, in contrast, experience such subjects as boring and tend to see them in terms of "a factory where you are there to work" or an "office where you learn to follow routine." Learning becomes work for those individuals who least benefit from its outcomes.

As other educationists point out, it is by resisting such boring work that many children cement their failure in increasingly competitive education markets. As Willis (1978) argued, working-class lads earn self-respect and the admiration of their peers by resisting schoolwork in the most imaginative ways they can contrive. Such resistance is fueled by particular notions of masculinity, where physical prowess is admired and bookish learning, pen pushing, and obedience to (women) teachers despised. In a cruel irony, the lads help produce their own class subordination through successful resistance to schoolwork. At home, the same lads resist what they see as effeminate housework. ${ }^{3}$

Keenly aware of intensified pressures to produce examination results, some parents attempt to override children's disinterest or outright resistance to school through payment by results of sorts, setting a fee for each high grade achieved, or supplying substantial inducements for major achievements, such as high school graduation. Many households are not in a position to provide such inducements, others (for whom the gaining of knowledge constitutes its own reward) condemn them as vulgar and mercenary. All, however, are expected to supply a certain amount of educational housework. Already in the nineteenth century, schools not only claimed increasing proportions of young peoples' energies but "made more work for mother" (or an older sibling) in requiring ever more stringent standards of dress and cleanliness, "school readiness," and homework supervision (Davin 1996; Griffith and Smith, 1987). Today, it is difficult for students to perform well in many educational hurdles without drawing extensively on the emotional, intellectual, and financial resources of their households, at times supplemented by homework clubs, coaching academies, or cram schools. 
Just as feminists campaign for more family-friendly workplaces and institutions so that both mothers and fathers can devote sufficient time to domestic and caring responsibilities, so it might be possible to demand school schedules that give young people sufficient time to do their share of housework. This, needless to say, is the last thing that most parents-and children-want. Not only could less intensely schooled children miss out in the competition for increasingly elaborate educational credentials, the time parents believe they need to allocate to child supervision would expand. Rather than celebrate the potential return of "useful housechildren," newspaper headlines would be likely to decry an increase in the number of latchkey children. In their final essays for a Canadian university course on contested childhoods I recently taught, some students argued that parents' work schedules must be altered to free their teenage sons and daughters from the remaining vestiges of domestic child labor.

\section{Conclusion}

In countries of the North, there are some housewives who hardly do any housework, but they are a social and statistical oddity. Men are a much more varied bunch. Though a substantial minority hardly lift a finger and a handful do a great deal, most contribute between a third and a quarter of domestic labor. What children do, in contrast, varies substantially both within and between countries. Some young people have never held a job, others work whole weekends, much of school holidays, and before and after school. A number of girls and fewer boys do an equitable share of housework, a few assume major responsibility for siblings or parents, and many hardly bring themselves to make their own bed. Some of this variation is linked to states and markets. These not only demand different amounts of schoolwork and provide different resources to the young but often affect minority groups in distinct ways. Statistics alone cannot tell us whether the social relations between mothers and children are more or less democratic, but they do indicate that girls and boys in many minority and mother-headed households have a greater propensity for domestic usefulness. In contrast, the offspring of many advantaged, highly educated parents do less and less around the home, expect prolonged support from their mothers and fathers, and sometimes take on paid work to earn additional income. Different cultural groups have divergent views regarding appropriate distribution of self-care and parenting tasks between toddlers and their carers; in some countries and social groups, unproductive but studious children have become valued symbols of respectability, supplementing and perhaps replacing the older figure of a full-time housewife. 
Everywhere, escalating competition for examination results requires intensified inputs into the production of scholars at home; to succeed, many social groups have invested in collective strategies of educational advancement.

On reflection, this diversity in young people's costs and usefulness might mean that accepted accounts of the transition from useful to precious children will need to be rewritten, guided by more precise historical questions. Did boys' and girls' emancipation from housework occur roughly at the same time and in the same way? How were (gender-specific) changes in wage remission practices negotiated in different localities and social groups? How were all these trends related to historic reversals in education participation rates of males and females? Were there distinct transitions in flows of effort and resources between the generations in different class and ethnic groups and between boys and girls, just as there have been different demographic transitions (Szreter 1996)? How are distinct forms of age relations related to different welfare state regimes? Equally important, have accounts of irreversible transitions to "modern" childhood and youth wrongly assumed that there is a single, one-way path to the future? What strategies for improving equity in the division of effort and resources between the generations might be appropriate in different circumstances, for different social groups? Such observations assume even more significance when we look at countries of the South.

Worldwide, the International Labour Organization estimates that a quarter of all children between ages five and fourteen work full-time; in Africa, the comparable figure is 41.4 percent (Moore 2000, 534). In many countries, children are major breadwinners, homeworkers, and sometimes heads of families or parents themselves. Much of their labor services households and local economies, but at times it constitutes an integral part of far-flung production chains of modern global industries. Home-based workers, many of them children, make up a significant share of the workforce in the textile and garment industries, the leather industry, carpet making, and electronics in both developed and developing economies (Portes et al. 1989). In India, child helpers collect and clean prawns that end up as fast food in the United States and Europe and help process coconut fiber used in fashionable rattan products (Nieuwenhuys 1994). In Africa, they assist in the collection of shea nuts for the cosmetics industry, in Latin America, they gather forest products used to manufacture alternative medicines (Carr et al. 2000). In Australia and the United States, around 20 percent of the population is fifteen years or younger; in Italy, Japan, and Spain, 14 percent. In contrast, in twenty-five countries, most of them in Africa, more than 44 percent 
of the population is under fifteen years of age. Although life expectancy in Australia, Canada, and Japan is over eighty years, children born in Sub-Saharan Africa can expect to live to the age of forty-seven. In Botswana, life expectancy is less than thirtythree years; in Zambia, just over thirty-five years (U.S. Census Bureau 2004).

In all these setting, as Moore (2000) notes in an excellent overview of development agencies and approaches, notions of "real" and priceless childhood are a hindrance rather than a help. It is also here that new forms of innovative and inspirational useful childhoods are beginning to emerge, shaped in part by activism of the young people themselves (Boyden et al. 1998; Levison 2000; Liebel et al. 2001). The statement of the First World Meeting of Working Children in Kundapur, India, in 1996 thus began with the words "We want recognition of our problems, initiatives, proposals and our process of organisation." It ended as follows: "We are against exploitation at work; but we are in favour of work with dignity and appropriate hours, so that we have time for education and leisure" (Liebel 2003, 269).

Despite recent emphases on diversity in much of social science, debates about growing up often share underlying assumptions regarding universal identities and patterns of social relations. How will social and technological developments transform the character of work, family life, childhood, and education in the twenty-first century? Will children remain useless or turn back into useful housechildren? The key message of this article is that there cannot be only one answer-and not only because the incomensurability of many people's lives stems from more or less personal relations of dependence, exploitation, and subordination. In countries of the North, significant minorities have not ceased to be useful now even as they prepare for future adult roles. The majority of young people, supported to a greater or lesser extent by welfare states, are net consumers of services at home even as they accumulate (or not) social capital at school. As more mothers opt out of full-time roles as housewives, such domestic uselessness is becoming increasingly problematic; arguably, it complements other causes of very low birth rates. In countries of the South, in contrast, a small minority is precious, but the majority has little option but to combine preparation for the future with current usefulness. It is this usefulness, in turn, which makes the childbearing of their mothers sustainable. On these and other fronts, relations between the generations will continue to be contested-by individuals, groups, and social movements. For all these reasons, age relations belong to the very center of social inquiry. 


\section{NOTES}

I am indebted to the constructive criticism of three reviewers in completing this paper.

1. The 1990 United Nations Convention on the Rights of Children defines a child as "every human being below the age of eighteen years, unless, under the law applicable to the child, majority is achieved earlier." I tend to use children for people up to the age of twelve, and young people for an overlapping category, roughly between the ages of six and eighteen. I also use children to designate a relationship with parents, irrespective of age.

2. Based on interviews with children between the ages of nine and fourteen from eleven schools around the United States, The Kids' Allowance $B o o k$, for example, chronicles a number of tips and negotiating strategies with parents. These include picking your own chores before mother has a chance to allocate you something you hate the very thought of doing, finding out what other kids earn so you can ask for a fair wage, reminding father the day before pocket money is due so he has the right change, asking for a slightly higher raise than you want so you can give in a little and still come out okay, and avoiding whining, begging, asking way too much, or not doing chores on time (Nathan 1988, 382-83).

3. Valuable as such studies have been, however, critics have pointed out that this approach romanticizes resistance, and ignores the bulk of the students who sit through lessons without causing a stir. For girls and resistance, see McRobbie (1978, 2000) and Hay (1997).

\section{REFERENCES}

Alanen, Leena. 1994. "Gender and Generation: Feminism and the 'Child Question.'” In Childhood Matters, ed. Jens Qvortrup, Marjatta Bardy, Giovanni Sgritta, and Helmut Wintersberger, 27-42. Aldershot, U.K.: Avebury.

Alsaker, Françoise D., and August Flammer, eds. 1999. The Adolescent Experience in Twelve Nations: European and American Adolescence in the Nineties. Hillsdale, N.J.: Lawrence Erlbaum.

Anderson, Bridget. 2000. Doing the Dirty Work: The Global Politics of Domestic Labour. London: Zed Books.

Ariés, Philippe. 1973. Centuries of Childhood. Harmondsworth: Penguin.

Backhouse, Constance. 1988. "Married Women's Property Law in Nineteenth-

Century Canada." Law and History Review 6(2): 211-57.

Bellingham, Bruce. 1988. "The History of Childhood since the "Invention of

Childhood': Some Issues in the Eighties." Journal of Family History 13(2): 347-58.

Bittman, Michael. 1999. "Parenthood without Penalty: Time Use and Public Policy in Australia and Finland." Feminist Economics 5(3): 27-42.

Bonke, Jens. 1999. "Children's Household Work: Is There a Difference between Girls and Boys?" IATUR Conference: The State of Time Use Research at the End of the Century, University of Essex, Colchester, U.K., 6-8 October. 
Boyden, Jo, Birgitta Ling, and William Meyers, eds. 1998. What Works for Working Children. Stockholm: Räddda Barnen.

Bradbury, Bruce, and Markus Jäntti. 2000. "Child Poverty across the Industrialised World: Evidence From the Luxembourg Income Study." In Child Well-being, Child Poverty and Child Policy in Modern Nations, ed. Koen Vleminckx and Timothy M. Smeeding, 1-32. Bristol, U.K.: Policy Press.

Brannen, Julia, 1996. "Discourses of Adolescence: Young People's Independence and Autonomy Within Families." In Children in Families: Research and Policy, ed. Julia Brannen and Margaret O'Brien, 101-13. Washington, D.C.: Falmer Press.

Caldwell, John C. 1980. "Mass Education as a Determinant of the Timing of Fertility Decline." Population and Development Review 6(2): 225-55.

Carr, Marilyn, Martha Alter Chen, and Jane Tate. 2000. "Globalization and Home-Based Workers." Feminist Economics 6(3): 123-42.

Christopher, Karen. 2002. "Caregiving, Welfare States, and Mothers' Poverty." In Child Care and Inequality: Re-thinking Carework for Children and Youth, ed. Francesca Cancian, Demi Kurz, Andrew London, Rebecca Reviere, and Mary Tuominen. New York: Routledge.

Cook, Thomas D., and Frank F. Furstenberg Jr. 2002. "Explaining Aspects of the Transition to Adulthood in Italy, Sweden, Germany and the United States: A Cross-Disciplinary, Case Synthesis Approach.” In Early Adulthood in Cross-National Perspective, ed. Frank F. Furstenberg, 103-33. Thousand Oaks, Calif.: Annals of the American Academy of Political and Social Science, Sage Publications.

Corrigan, Philip. 1990. Social Forms/Human Capacities. London: Routledge.

Cott, Nancy F. 2000. Public Wows: A History of Marriage and the Nation. Cambridge, Mass.: Harvard University Press.

Davin, Anna. 1996. Growing up Poor: Home and Street in London 1870-1914. London: Rivers Oram Press.

Driscoll, Catherine. 2002. Girls: Feminine Adolescence in Popular Culture and Cultural Theory. New York: Columbia University Press.

Folbre, Nancy. 1994. Who Pays for the Kids? Gender and the Structures of Constraint. London: Routledge.

Friedman, Debra, Michael Hechter, and Satoshi Kanazawa. 1999. "Theories of the Value of Children: A New Approach." In Dynamics of Values in Fertility Change, ed. Richard Leete, 19-50. Oxford: Oxford University Press.

Gager, Constance T. 1998. "The Role of Valued Outcomes, Justifications, and Comparison Referents in Perceptions of Fairness among Dual-Earner Couples.” Journal of Family Issues 19(5): 622-49.

Gill, Gurjeet K. 1998. “The Strategic Involvement of Children in Housework: An Australian Case of Two-Income Families." International Journal of Comparative Sociology 39(3): 301-15.

Gillis, John R. 1981. Youth and History: Transition and Change in European Age Relations, 1770 to the Present. New York: Academic Press.

Goldscheider, Frances K., and Linda J. White. 1991. New Families, No Families? The Transformation of the American Home. Berkeley: University of California Press. 
Goodnow, Jacqueline J. 2002. "Adding Culture to Studies of Development: Toward Changes in Procedure and Theory." Human Development 45(4): 237-45.

Goodnow, Jacqueline J., and Ailsa Burns. 1985. Home and School: Child's Eye View. Sydney: Allen \& Unwin.

Gordon, Linda. 1989. Heroes of Their Own Lives: The Politics and History of Family Violence. London: Virago.

Graff, Harvey J. 1991. "Remaking Growing Up: Nineteenth-Century America." Histoire Sociale-Social History 24(47): 35-59.

Griffith, Alison I., and Dorothy E. Smith. 1987. "Constructing Cultural Knowledge: Mothering as Discourse." In Women and Education: A Canadian Perspective, ed. Jane Gaskell and A. McLaren, 87-103. Calgary: Detseling Enterprises.

Hawes, Joseph M., and N. Ray. Hiner, eds. 1991. Children in Historical and Comparative Perspective: An International Handbook. New York: Greenwood Press.

Hay, Valerie. 1997. The Company She Keeps: An Ethnography of Girls' Friendships. Buckingham, U.K.: Open University Press.

Henriques, Julian, Wendy Hollway, Cathy Urwin, Couze Venn, and Valerie Walkerdine. 1984. Changing the Subject: Psychology, Social Regulation and Subjectivity. London: Methuen.

Heitlinger, Alena. 1993. Women's Equality, Demography and Public Policies. New York: St. Martin's Press.

Hochschild, Arlie R. 1997. The Time Bind: When Work Becomes Home and Home Becomes Work. New York: Metropolitan Books.

- 2003. The Commercialization of Intimate Life: Notes from Home and Work. Berkeley: University of California Press.

Hochschild, Arlie R., and Barbara Ehrenreich, eds. 2002. Global Woman: Nannies, Maids, and Sex Workers in the New Economy. New York: Metropolitan Books.

Hofferth, Sandra L., and John F. Sandberg. 2001. "How American Children Spend Their Time." Journal of Marriage \& Family 63(2): 295-308.

Hogan, David J. 1985. Class and Reform: School and Society in Chicago, 1880-1930. Philadelphia: University of Pennsylvania Press.

Iacovou, Maria. 2002. "Regional Differences in the Transition to Adulthood." In Early Adulthood in Cross-National Perspective, ed. Frank F. Furstenberg, 40-69. Thousand Oaks, Calif.: Annals of the American Academy of Political and Social Science, Sage Publications.

Ironmonger, Duncan. 1996. "Counting Outputs, Capital Inputs and Caring Labour: Estimating Gross Household Product.” Feminist Economics 2(3): 37-64.

Jenson, Jane, and Denis Saint-Martin. 2003. "New Routes to Social Cohesion? Citizenship and the Social Investment State." Canadian Journal of Sociology 28(1): 77-99.

Johansson, S. Ryan. 1987. "Centuries of Childhood/Centuries of Parenting: Philippe Arifis and the Modernization of Privileged Infancy." Journal of Family History 12(4): 343-65. 
Johnson, Heather B. 2001. "From the Chicago School to the New Sociology of Children: The Sociology of Children and Childhood in the United States, 1909-1999." In Children at the Millennium: Where Have We Come from, Where Are We Going? ed. Sandra L. Hofferth and Timothy J. Owens, 53-93. Amsterdam: JAI, Elsevier Science.

Kett, Joseph, F. 1978. "Curing the Disease of Precocity." In Turning Points, Historical and Sociological Essays on the Family, ed. John Demos and Sarane Spence Boocock, S183-S211. Chicago: University of Chicago Press.

Krause, Elizabeth L. 1999. "Natalism and Nationalism: the Political Economy of Love, Labor, and Low Fertility in Central Italy." PhD diss., University of Arizona. Ann Arbor: UMI Dissertation Services photocopy.

Larson, Reed W., and Suman Verma. 1999. "How Children and Adolescents Spend Time across the World: Work, Play, and Developmental Opportunities." Psychological Bulletin 125(6): 701-36.

Lavalette, Michael. 1966. “Thatcher's Working Children: Contemporary Issues of Child Labour." In Thatcher's Children? Politics, Childhood and Society in the 1980s and 1990s, ed. Jane Pilger and Stephen Wagg, 172200. London: Palmer Press.

Layne, Linda L., ed. 1999. Transformative Motherhood: on Giving and Getting in a Consumer Culture. New York: New York University Press.

Lee, Yun-Suk, and Linda J. Waite. Forthcoming. "How Much Time Do Husbands and Wives Spend on Housework? Estimates Depend on Who You Ask, How You Ask, and What You Ask." Journal of Marriage and the Family.

Lee, Yun-Suk, Barbara Schneider, and Linda J. Waite. Forthcoming. "Children and Housework: Some Unanswered Questions." In Social Studies of Children and Youth 9, ed. K. B. Rosier. Stamford Conn: JAI Press/Ablex Publishing.

Levison, Deborah. 2000. "Children as Economic Agents." Feminist Economics 6, no. 1: 125-34.

Liebel, Manfred. 2003. "Working Children as Social Subjects: The Contribution of Working Children's Organizations to Social Transformations." Childhood 10(3): 265-85.

Liebel Manfred, Bernd Overwien and Albert Recknagel, eds. 2001. Working Children's Protagonism: Social Movements and Empowerment in Latin America, Africa and India. Frankfurt am Main and London: IKO-Verlag für Interkulturelle Kommunikation.

Lister, Ruth 2002. "Investing in the Citizen-Workers of the Future: New Labour's 'Third Way' in Welfare Reform.” Working Paper no. 5, available online at http://www.fas.umontreal.ca/pol/cohesionsociale.

Malin, Merridy, Katho Campbell, and Laura Agius. 1997. "Raising Children in the Nunga Aboriginal Way." Bedrock 2(4): 20-26.

Matthews, Beverly J. 1999. "The Gender System and Fertility: An Exploration of the Hidden Links." Canadian Studies in Population 26(1): 21-38.

McDonald, Peter F. 2000. "Gender Equity, Social Institutions and the Future of Fertility." Journal of Population Research 17(1): 1-16. 
McKechnie, Jim, Michael Lavalette, and Sandy Hobbs. 2000. "Child Employment Research in Britain." Work, Employment and Society 14(3): 573-80.

McNeal, James U. 1999. The Kids Market. Ithaca, NY: Paramount.

McRobbie, Angela. 1978. "Working Class Girls and the Culture of Femininity." In Women Take Issue, 96-108. Women's Studies Group, Centre for Contemporary Cultural Studies, University of Birmingham. London: Hutchinson.

- 2000. Feminism and Youth Culture, 2nd ed. London: Macmillan.

Miller, Pavla. 1986. Long Division: State Schooling in South Australian Society. Adelaide, Australia: Wakefield Press.

- 1998. Transformations of Patriarchy in the West, 1500-1900. Bloomington: Indiana University Press.

- 2002. "Reinventing Mastery, Service and Social Infancy: Patriarchal Legal Precedents of Age, Gender and Class Relations." History of Education Review 31(1): 1-18.

Mitterauer, Michael. 1993. A History of Youth. Oxford: Blackwell.

Mizen, Phillip, Angela Bolton, and Christopher Pole. 1999. "School Age Workers: The Paid Employment of Children in Britain." Work, Employment and Society 13(3): 423-38.

Moore, Karen. 2000. "Supporting Children in Their Working Lives: Obstacles and Opportunities Within the International Policy Environment.” Journal of International Development 12: 531-48.

Morrow, Virginia. 1996. "Rethinking Childhood Dependency: Children's Contributions to the Domestic Economy." Sociological Review 44(1): 58-77.

Musgrove, F. 1964. "The Invention of the Adolescent." In Youth and the Social Order, ed. F. Musgrove, 58-85. London: Routledge and Kegan Paul.

Nathan, Amy. 1998. The Kids' Allowance Book. New York: Walker.

Nieuwenhuys, Olga. 1994. Children's Lifeworlds: Gender, Welfare and Labour in the Developing World. London: Routledge.

- 1996. "The Paradox of Child Labor and Anthropology." Annual Review of Anthropology 25: 237-51.

Oakley, Ann. 1994. "Women and Children First and Last: Parallels and Differences between Children's and Women's Studies." In Children's Childhoods: Observed and Experienced, ed. Berry Mayall, 15-20. London: Falmer Press.

Olsen, Richard. 2000. "Families under the Microscope: Parallels between the Young Carers Debate of the 1990s and the Transformation of Childhood in the Late Nineteenth Century." Children and Society 14(5): 384-94.

Orellana, Majorie F. 2001. "The Work Kids Do: Mexican and Central American Immigrant Children's Contributions to Households and Schools in California." Harvard Educational Review 71(3): 366-89.

Portes, Alejandro, Manuel Castells and Laura Benton, eds. 1989. Informal Economy: Studies in Advanced and Less Developed Countries. Baltimore, Md.: Johns Hopkins University Press.

Press, Julie E., and Eleanor Townsley. 1998. "Wives' and Husbands' Housework Reporting: Gender, Class, and Social Desirability." Gender \& Society 12(2): 188-218. 
Prout, Alan, and Alison James. 1997. “A New Paradigm for the Sociology of Childhood? Provenance, Promise and Problems." In Constructing and Reconstructing Childhood: Contemporary Issues in the Sociological Study of Childhood, ed. Alison James and Alan Prout, 7-33. London: Falmer Press.

Qvortrup, Jens. 1995. "From Useful to Useful: The Historical Continuity of Children's Constructive Participation.” Sociological Studies of Children 7: 49-76.

Ridge, Tess. 2002. Childhood Poverty and Social Exclusion: From a Child's Perspective. Bristol, U.K.: Policy Press.

Rikowski, Glenn, and Mike Neary. 1997. "Working School Children in Britain Today." Capital and Class 63: 25-35.

Roche Jeremy, and Stanley Tucker. 2003. "Extending the Social Exclusion Debate: An Exploration of the Family Lives of Young Carers and Young People with ME." Childhood 10(4): 439-56.

Shanley, Mary L. 1989. Feminism, Marriage and the Law in Victorian England, 1850-1895. Princeton, N.J.: Princeton University Press.

Shrift, Alan D. 1997. The Logic of the Gift: Toward An Ethic of Generosity. New York: Routledge.

Siegel, Reva B. 1994. "The Modernization of Marital Status Law: Adjudicating Wives' Rights to Earnings, 1860-1930.” Georgetown Law Journal 82(7): 2127-211.

Silbaugh, Katherine. 1996. “Turning Labor into Love: Housework and the Law." Northwestern University Law Review 91(1): 1-87.

Smeeding, Timothy S. and Katherin Ross Phillips. 2002. "Cross-national Differences in Employment and Economic Sufficiency." In Early Adulthood in Cross-National Perspective, ed. Frank F. Furstenberg, 103-33. Thousand Oaks, Calif.: Annals of the American Academy of Political and Social Science, Sage Publications.

Solberg, Anne. 1997. "Negotiating Childhood: Changing Constructions of Age for Norwegian Children." In Constructing and Reconstructing Childhood: Contemporary Issues in the Sociological Study of Childhood, ed. Alison James and Alan Prout, 126-44. London: Falmer Press.

Song, Miri. 1996. “'Helping Out': Children's Labour Participation in Chinese Take-Away Businesses in Britain." In Children in Families: Research and Policy, ed. Julia Brannen and Margaret O'Brien, 101-13. London \& Washington, D.C.: Falmer Press.

- 1999. Helping Out: Children's Labour in Ethnic Businesses. Philadelphia: Temple University Press.

Stanley, Amy D. 1998. From Bondage to Contract: Wage Labor, Marriage and the Market in the Age of Slave Emancipation. Cambridge: Cambridge University Press.

Szreter, Simon. 1996. Fertility, Class and Gender in Britain, 1860-1940. Cambridge: Cambridge University Press.

Teese, Richard, and John Polesel. 2003. Undemocratic Schooling: Equity and Quality in Mass Education in Australia. Melbourne: Melbourne University Press. 
Thorne, Barrie. 1987. "Re-Visioning Women and Social Change: Where Are the Children?" Gender and Society 1(1): 85-109.

Tilly, Charles. 1973. "Population and Pedagogy in France." History of Education Quarterly 13: 113-28.

U.S. Census Bureau, International Data Base, http://www.census.gov/ipc/ www/idbnew.html, accessed 30 May 2004.

Valenzuela, Abel Jr. 1999. "Gender Roles and Settlement Activities among Children and Their Immigrant Families." American Behavioral Scientist 42(4): $720-42$.

Waring, Marilyn. 1988. Counting for Nothing: What Men Value and What Women Are Worth. Sydney: Allen and Unwin.

Willis, Paul. 1978. Learning to Labour: How Working Class Kids Get Working Class Jobs. Westmead, U.K.: Saxon House.

Zelizer, Viviana A. 1985. Pricing the Priceless Child: The Changing Social Value of Children. New York: Basic Books.

—. 2002. "Kids and Commerce." Childhood 9(4): 375-96. 